\title{
Aspek Genetik Sindrom Nefrotik Resisten Steroid
}

\author{
Dedi Rachmadi \\ Bagian Ilmu Kesehatan Anak \\ Fakultas Kedokteran Universitas Padjadjaran \\ Rumah Sakit Hasan Sadikin, Bandung
}

\begin{abstract}
Abstrak
Sindrom nefrotik resisten steroid adalah sindrom nefrotik yang tidak mengalami remisi setelah diberikan terapi standar steroid. Sampai saat ini mekanisme resistensi terhadap steroid melalui dua hal, yaitu nongen yang berkaitan erat dengan dasar imunologis dan gen yang berupa defek primer pada barier filtrasi glomerulus. Dalam tulisan ini akan diungkapkan gen yang sudah diketahui terlibat dalam patogenesis terjadinya sindrom nefrotik resisten steroid. Gen ini menyandi protein yang membentuk struktur celah diafragma glomerulus. Bila terjadi mutasi gen ini akan mengakibatkan perubahan pada arsitektur celah diafragma glomerulus, yaitu terjadi pendataran foot processes podosit sehingga terjadi proteinuria berat. Sampai saat ini telah ditemukan delapan gen penyandi protein podosit, yaitu: NPHS1, ACTN4, NPHS2, CD2AP, WT1, TRPC6, LAMB2, dan yang paling ahir diketahui yaitu NPHS3. Protein yang disandi oleh gen-gen tersebut adalah: nefrin, $\alpha$-aktinin-4, podosin, CD2-associated protein, Wilms' tumor, transient receptor potential 6, laminin $\beta 2$ chain, dan phospholipase PLCE1. Manifestasi klinis sindrom nefrotik resisten steroid akibat adanya mutasi gen-gen ini umumnya lebih berat, onset terjadinya penyakit lebih awal, dan cepat mengalami perburukan menjadi gagal ginjal terminal. Aspek genetis sindrom nefrotik resisten steroid perlu diketahui untuk memperkirakan perjalanan dan prognosis penyakit. [MKB. 2010;42(1):37-44].
\end{abstract}

Kata kunci: Aspek genetik, sindrom nefrotik resisten steroid

\section{Genetic Aspect of Steroid Resistant Nephrotic Syndrome}

\begin{abstract}
Steroid resistant neprotic syndrome are patients who showed no remission after standard therapy of steroid. Until now, steroid resistant mechanism occurs through two ways, that are non gene that related with immunologic based and gene related with primary defect on glomerular filtration barrier. This paper describes those genes known related to the pathogenesis of steroid resistant nephrotic syndrome. These genes code glomerular slit diaphragm proteins. Mutation of these genes will cause changes on glomerular slit diaphragm architecture that is flattening of foot processes of podocyte which cause severe proteinuria. Recently, there are found 8 genes that code podocyte proteins: NPHS1, ACTN4, NPHS2, CD2AP, WT1, TRPC6, and LAMB2, last found is NPHS3 gene. Proteins coded by those genes are: nefrin, $\alpha$-actinine-4, podosine, CD2-associated protein, Wilms' tumor, transient receptor potential 6 , laminin $\beta 2$ chain, and phospholipase PLCE1. Clinical manifestation of steroid resistant nephrotic syndrome caused by mutation of these genes generally severe, earlier onset of illness and worsen to end stage kidney failure. We need to know about genetic aspect of steroid resistant neprotic syndrome to predict the progression and prognosis of the disease. [MKB. 2010;42(1):37-44].
\end{abstract}

Key words: Genetic aspect, steroid resistant neprotic syndrome

Korespondensi: Dr. dr. Dedi Rachmadi, SpA(K)., Mkes., Bagian Ilmu Kesehatan Anak, Fakultas Kedokteran Universitas Padjadjaran, Rumah Sakit Hasan Sadikin, Jln. Pasteur 38 Bandung, Tlp. (022) 2034426/(022) 2035957,

Email:dedirachmadi@yahoo.com 


\section{Pendahuluan}

Sindrom nefrotik (SN) merupakan penyakit glomerulus yang paling sering ditemukan pada anak. Kebanyakan SN pada anak memberikan respons terhadap pengobatan kortikosteroid (prednison/prednisolon), hanya $10-20 \%$ yang tidak memberikan respons terhadap pengobatan kortikosteroid. $^{1-3}$ Disebut SN sensitif steroid (SNSS) bila penderita memberikan respons dan terjadi remisi dalam empat minggu pengobatan kortikosteroid, sedangkan bila tidak mengalami remisi disebut $\mathrm{SN}$ resisten steroid (SNRS). Walaupun persentase SNRS relatif kecil tetapi $50 \%$ penderita SNRS anak ras kulit putih dalam waktu 5 tahun dan $80 \%$ anak ras Afrika-Amerika dalam waktu 3 tahun akan mengalami komplikasi ekstrarenal dan berkembang menjadi gagal ginjal terminal.

Mekanisme resistensi terhadap steroid pada penderita SN terjadi melalui dua hal, yaitu nongen yang berkaitan erat dengan dasar imunologis dan gen yang berupa defek primer pada barier filtrasi glomerulus. Baik kelainan dasar imunologis maupun gen mungkin saling mempengaruhi terhadap terjadinya resistensi steroid pada penderita SN. ${ }^{4}$ Dalam beberapa tahun terahir ini telah berkembang pesat mengenai penelitian genetik molekuler yang sampai saat ini telah ditemukan delapan gen yang terlibat dalam patogenesis SN, yaitu gen yang mengkode sintesis protein yang berperan untuk mempertahankan struktur celah diafragma glomerulus. Adanya mutasi pada gen-gen ini menyebabkan celah diafragma melebar, sehingga terjadi proteinuria yang berat. ${ }^{4-6}$

Berdasarkan hasil penelitian akhir-akhir ini menunjukkan bahwa SN yang disebabkan mutasi gen memberikan manifestasi klinis yang lebih berat, onset lebih awal, tidak memberikan respons terhadap pengobatan steroid, dan dapat cepat berkembang menjadi gagal ginjal terminal. Tujuan penulisan makalah ini adalah mengungkap aspek genetik sebagai salah satu mekanisme patogenesis terjadinya sindrom nefrotik berat dengan melihat manifestasi klinisnya sehingga dapat memperkirakan perjalanan dan prognosis penyakit.

\section{Patofisiologi SN Resisten Steroid (SNRS)}

Penyebab proteinuria pada SN adalah kerusakan fungsi atau struktur membran filtrasi glomerulus. Membran filtrasi glomerulus terdiri dari endotel fenestra sebelah dalam, membran basalis dan sel epitel khusus di bagian luar yang dikenal dengan podosit, seperti terlihat pada Gambar 1. Podosit memiliki tonjolan-tonjolan menyerupai kaki (foot processes), di antara tonjolan-tonjolan tersebut terdapat celah diafragma (slit diaphragm), yang berperan penting dalam pemeliharaan fungsi filtrasi glomerulus.

Terdapat dua mekanisme yang berperan pada patogenesis SN, yaitu pertama secara imunologis sel $\mathrm{T}$ memproduksi circulating factor, berupa vascular permeability factor (VPF) yang merupakan asam amino identik dengan vascular

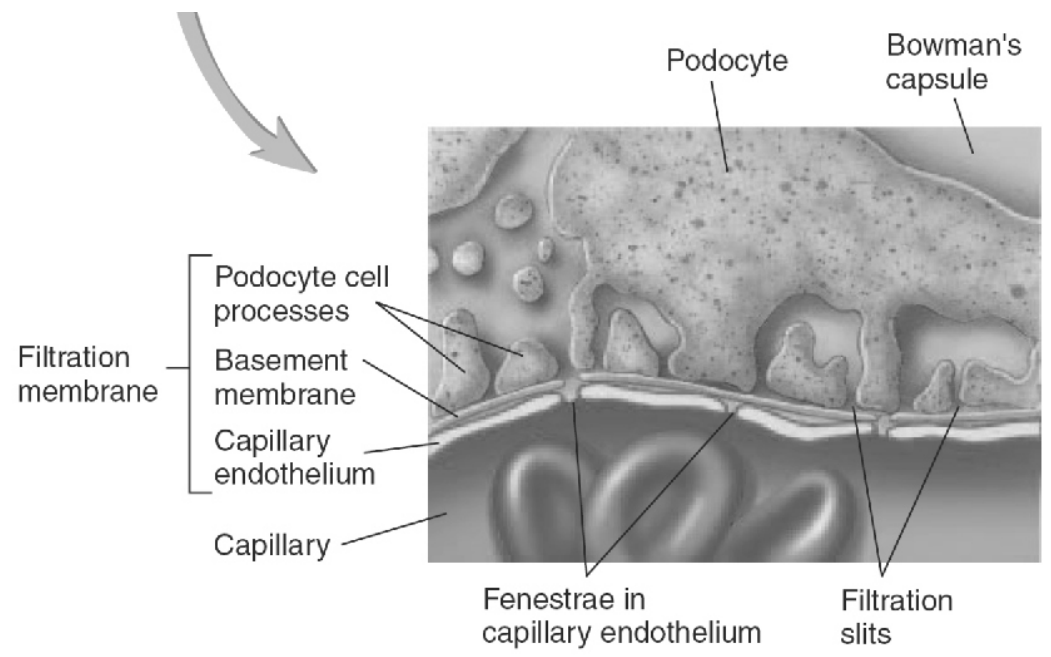

Gambar 1 Membran Filtrasi Glomerulus 


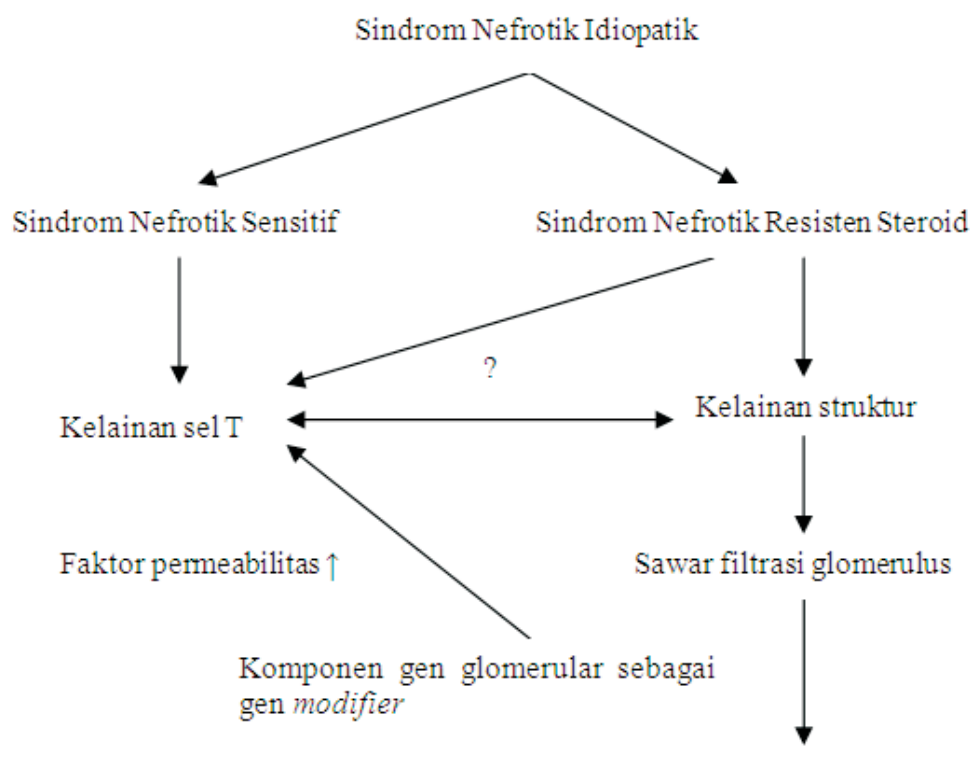

Tidak ada kekambuhan setelah transplantasi

\title{
Gambar 2 Mekanisme Dasar Sindrom Nefrotik Idiopatik
}

\author{
Sumber: Antignac ${ }^{4}$
}

endhotelial growth factor (VEGF). Hal ini menyebabkan meningkatnya permeabilitas kapiler glomerulus sehingga terjadi kebocoran protein. Mekanisme kedua adalah terdapatnya defek primer pada barier filtrasi glomerulus yang mengakibatkan celah diafragma melebar. ${ }^{4}$ Mekanisme patogenesis SN dapat dilihat pada Gambar 2.

Zat-zat terlarut yang dapat melewati sawar glomerulus ditentukan oleh besarnya molekul, molekul $>10 \mathrm{kDa}$ akan ditahan sehingga tidak dapat melewati sawar tersebut (size-selectivity barrier). Bila ada gangguan pada mekanisme ini menyebabkan proteinuria baik protein dengan berat molekul kecil maupun protein dengan berat molekul besar (proteinuria nonselektif). Faktor lain yang dapat mempengaruhi adalah adanya daya elektrostatik dari muatan negatif permukaan molekul pada epitel foot processes yang dibentuk oleh sialoprotein kapiler, heparan sulfat membran basalis glomerulus, dan podokaliksin (chargeselectivity barrier). Gangguan pada daya elektrostatik tersebut menyebabkan proteinuria selektif (protein dengan berat molekul $\leq$ berat molekul albumin dapat melewati membran filtrasi glomerulus). Kerusakan struktur dan sawar elektrostatik ini menyebabkan banyaknya protein plasma yang melewati filtrasi glome-rulus. ${ }^{8}$ Pada penderita SNRS diduga selain charge-selectivity barrier juga berperan size-selectivity barrier yang menyebabkan protein-uria yang keluar selain berat molekul rendah (selektif) juga protein dengan berat molekul tinggi (nonselektif).

Hilangnya atau pendataran foot processes podosit yang tampak dengan mikroskop elektron memperlihatkan peran kunci podosit dalam patogenesis sindrom nefrotik idiopatik. Perubahan pada foot processes ini sebagai target circulating factor atau bagian dari perubahan struktur akibat adanya mutasi gen. Pada focal segmental glomerulosclerosis (FSGS) selain hilangnya foot processes podosit, juga terjadi peningkatan dari matriks ekstraselular dalam glomerulus disertai dengan menghilangnya lumen kapiler glomerulus. Lesi sklerotik ini terjadi secara fokal dan dalam beberapa segmen glomeruli serta secara tipikal tidak berhubungan dengan deposit kompleks imun. ' Rusaknya podosit terjadi melalui empat mekanisme utama, yaitu: perubahan komponen slit diaphragm atau gangguan pada struktur, disregulasi aktin sitoskeleton, perubahan membran basalis glomerulus atau interaksinya dengan podosit, dan perubahan muatan negatif permukaan podosit. ${ }^{9-11}$

Pada penderita SNRS terjadi perubahan baik pada fungsi maupun pada struktur ginjal yang mengarah ke glomerulosklerosis. Perubahan yang terjadi dapat berupa perubahan struktur sel-sel 
tertentu yang digantikan oleh fibroblas, kolagen, deposit lemak, dan matriks mesangial. Akibat lain, nefron yang tersisa akan melakukan penyesuaian terhadap keadaan tersebut sehingga beban nefron yang tersisa makin berat sampai pada akhirnya akan berubah menjadi jaringan parut dan terjadi kehilangan nefron yang lebih banyak. Hal inilah yang membuat prognosis SNRS buruk karena kejadian di atas mengarahkan penderita ke gagal ginjal terminal. $^{12}$

\section{Peranan Genetik Terhadap Patogenesis Sindrom Nefrotik}

Kemajuan pengetahuan tentang mutasi gen serta peranannya terhadap fungsi dan struktur celah diafragma glomerulus dapat menjelaskan akan terjadinya proteinuria, hal ini sangat membantu untuk diagnosis dan pendekatan tatalaksana sindrom nefrotik resisten steroid. ${ }^{8}$ Penelitian genetik dewasa ini pada kasus SN familial telah dapat mengidentifikasi protein podosit baru yang memegang peran penting pada protein podosit dalam membentuk arsitektur celah diafragma. Pada teknik metode kloning telah berhasil dalam mendapatkan gen ACTN4 yang dapat menyandi podocyte actin-binding protein $\alpha$-actinin 4 sebagai gen penyebab beberapa kasus FSGS otosom dominan. ${ }^{4}$ Selain itu dengan metode yang sama telah berhasil dilakukan kloning gen NPHS1 dan NPHS2 yang menyandi protein nefrin dan podosin, dan protein ini juga dapat membentuk arsitektur celah diafragma. Mutasi gen NPHS1 dapat menyebabkan terjadinya SN kongenital tipe Finnish (CNF). Mutasi gen NPHS2 berperan dalam terjadinya sindrom nefrotik resisten steroid familial dengan karakteristik awitan proteinuria pada usia dini, progresivitas menjadi gagal ginjal terminal yang cepat, dan tidak terjadi kekambuhan setelah menjalani transplantasi. ${ }^{4,13}$

Hingga saat ini telah dikenal 8 gen penyandi protein podosit yang mempunyai peranan terhadap fungsi podosit. Mutasi gen-gen tersebut dapat mengakibatkan terjadinya sindrom nefrotik berat, yaitu: NPHS1, ACTN4, NPHS2, CD2AP, WT1, TRPC6, LAMB $2{ }^{8}$ dan yang paling ahir diketahui yaitu gen NPHS3 yang menyebabkan diffuse mesangial sclerosis. ${ }^{14}$ Protein yang disandi oleh gen-gen tersebut adalah: nefrin, $\alpha$-aktinin-4, podosin, CD2-associated protein, Wilms' tumor, transient receptor potential 6 , laminin $\beta 2$ chain, dan phospholipase PLCE1. Pada Gambar 3 menunjukkan protein dari komponen podosit yang membentuk arsitektur dari celah diafragma glomerulus yang dapat mempengaruhi fungsi podosit. ${ }^{8}$ Protein tersebut disandi oleh gen yang berhubungan dengan SN. Gen yang berperan pada patogenesis $\mathrm{SN}$ resisten steroid tersebut dapat dilihat pada Tabel 1.

\section{Gen yang Berperan Sebagai Penyandi Protein Podosit}

\section{Nefrin (NPHS1)}

NPHS1 adalah gen yang terletak pada kromosom 19q13.1 dengan ukuran $26 \mathrm{~kb}$, terdiri dari 29 ekson. ${ }^{8}$ Gen ini menyandi pembentukan nefrin, protein dengan ukuran $136 \mathrm{kDa}$ yang merupakan molekul protein pertama yang diidentifikasi pada celah diafragma. ${ }^{6}$ Gen ini adalah gen pertama yang dihubungkan dengan sindrom nefrotik pada manusia, mutasi gen ini banyak didapat pada populasi di Finlandia. Terdapat dua jenis mutasi utama yaitu Fin-mayor dan Fin-minor yang menempati 97\% dari seluruh kasus. Mutasi dari Fin-mayor mengakibatkan terpotongnya protein nefrin hanya 90 asam amino dan Fin-minor akan mengakibatkan terpotongnya protein hingga 1.190 asam amino. $^{15}$

Pada mutasi gen NPHS1 terdapat lesi ginjal berat yang terjadi dalam satu bulan pertama kehidupan. Ditemukan sklerosis glomerulus yang

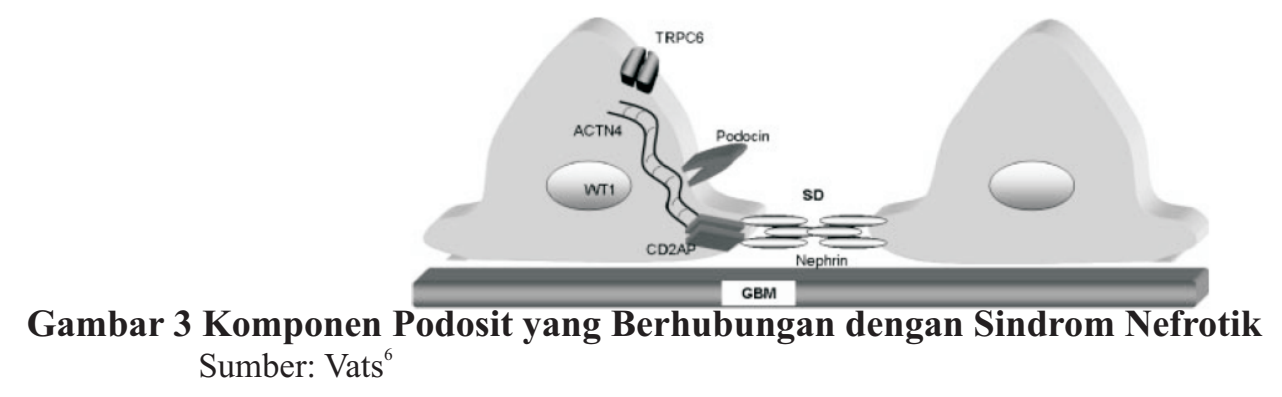


Tabel 1 Gen yang Berperan pada Sindrom Nefrotik yang Diturunkan

\begin{tabular}{|c|c|c|c|c|c|c|}
\hline Penyakit & $\begin{array}{l}\text { Gen } \\
\text { Lokasi }\end{array}$ & Protein & Diturunkan & $\begin{array}{c}\text { Usia } \\
\text { awitan }\end{array}$ & Anomali & $\begin{array}{c}\text { Kekambuhan } \\
\text { setelah } \\
\text { Transplantasi }\end{array}$ \\
\hline CNF & $\begin{array}{l}\text { NPHS1 } \\
19 q 13.1\end{array}$ & Nefrin & $\begin{array}{l}\text { Otosom } \\
\text { resesif }\end{array}$ & $\begin{array}{l}\text { Prenatal } \\
\text { usia dini }\end{array}$ & - & $20-25 \%$ \\
\hline SNRS & $\begin{array}{l}\text { NPHS2 } \\
\text { 1q25-31 }\end{array}$ & Podosin & $\begin{array}{l}\text { Otosom } \\
\text { resesif }\end{array}$ & $\begin{array}{l}\text { Usia anak, } \\
\text { awal } \\
\text { dewasa }\end{array}$ & - & $8 \% ?$ \\
\hline FSGS1 & $\begin{array}{l}\text { ACTN4 } \\
19 q 13\end{array}$ & a4aktinin & $\begin{array}{l}\text { Otosom } \\
\text { dominan }\end{array}$ & $\begin{array}{l}\text { awal } \\
\text { dewasa }\end{array}$ & - & \\
\hline FSGS2 & $\begin{array}{l}\text { TRPC6 } \\
11 \mathrm{q} 21-22\end{array}$ & TRPC6 & $\begin{array}{l}\text { Otosom } \\
\text { dominan }\end{array}$ & Dewasa & - & \\
\hline $\begin{array}{l}\text { FSGS3 } \\
\text { (mencit) }\end{array}$ & $\begin{array}{l}\text { CD2AP } \\
6 \mathrm{p} 12\end{array}$ & CD2AP & $\begin{array}{l}\text { Otosom } \\
\text { dominan }\end{array}$ & ? & - & \\
\hline $\begin{array}{l}\text { Sindrom Frasier } \\
\text { Sindrom Denys- } \\
\text { Drash }\end{array}$ & $\begin{array}{l}\text { WT1 } \\
11 \mathrm{p} 13\end{array}$ & $\begin{array}{l}\text { Faktor } \\
\text { transkripsi }\end{array}$ & & Usia dini & $\begin{array}{l}\text { Pseudoherma } \\
\text { froditisme }+ \\
\text { tumor Wilms }\end{array}$ & \\
\hline Sindrom Pierson & $\begin{array}{l}\text { LAMB2 } \\
3 \mathrm{p} 14-22\end{array}$ & $\begin{array}{l}\text { Rantai } \\
\text { laminin } \beta 2\end{array}$ & $\begin{array}{l}\text { Otosom } \\
\text { resesif }\end{array}$ & Prenatal & & $\begin{array}{l}\text { Abnormalitas } \\
\text { mata }\end{array}$ \\
\hline $\begin{array}{l}\text { Diffuse } \\
\text { mesangial } \\
\text { Sclerosis }\end{array}$ & $\begin{array}{l}\text { NPHS3 } \\
10 q 23\end{array}$ & $\begin{array}{l}\text { Fosfolipase } \\
\text { PLCE1 }\end{array}$ & & Usia dini & & \\
\hline
\end{tabular}

dapat berkembang menjadi sklerosis mesangial progresif dengan konsekuensi akan terjadinya obliterasi kapiler. Glomerulus menjadi berkurang, sedangkan oklusi tubulus yang terbuka atau protrusi glomerulus kedalam ruang subepitelial atau melalui kapsul Bowman tidak ditemukan. Beberapa sel inflamasi dapat dideteksi di daerah mesangial. Sel epitel glomerulus (podosit) akan terlihat mengalami perubahan ultrastruktural dan hipertrofi. Akibat semua proses tersebut adalah terjadinya lesi endokapiler yang berperan penting dalam proses sklerosis di glomerulus. ${ }^{15}$

\section{CD2-associated protein (CD2AP)}

Gen CD2AP terletak pada kromosom 6 lengan panjang (6p12), gen ini menyandi protein domain $\mathrm{SH} 3$ dengan molekul $80 \mathrm{kDa}$ yang berfungsi untuk menstabilkan hubungan antara sel $\mathrm{T}$ dan sel antigen-presenting. CD2AP memiliki N-terminus yang berikatan dengan aktin di dalam sel. Gen ini merupakan molekul multifunctional adapter-type yang berada dalam sitoplasma, ikatannya dengan aktin menunjukkan peranannya dalam melakukan regulasi dinamis sitoskeleton aktin. ${ }^{6}$ CD2AP diekspresikan pada podosit di permukaan sitoplasma celah diafragma glomerulus.
Beberapa hasil penelitian menunjukkan bahwa CD2AP berinteraksi dengan nefrin dan keduanya terlibat dalam penanda intraselular. Peran CD2AP dalam sindrom nefrotik atau patogenesis FSGS ditemukan secara tidak sengaja saat CD2AP yang ditekan pada mencit berkembang menjadi penyakit menyerupai SN dan mati dalam enam minggu akibat gagal ginjal. Pada keadaan ini ditemukan beberapa gambaran patologi FSGS, seperti proliferasi sel mesangial dengan deposisi matriks ekstraselular dan glomerulosklerosis yang disertai hilangnya foot processes yang luas, penyakit ini disebut juga FSGS3. Penelitian pada akhir-akhir ini menunjukkan bahwa defek dari gen CD2AP dapat menyebabkan penyakit baik dalam bentuk homozigot(otosom resesif) maupun heterozigot. ${ }^{6}$

\section{Podosin (NPHS2)}

Gen NPHS2 terletak pada kromosom 1q25-q31, terdiri dari 8 ekson, mutasinya telah diketahui sebagai penyebab SN resisten steroid pada anak usia awitan dini. Gen NPHS2 menyandi protein podosin yang terdiri dari 383 asam amino. Podosin termasuk kedalam kelompok stomatin, merupakan salah satu protein membran yang penting dan secara khusus diekspresikan pada foot processes podosit. ${ }^{6,8}$ Podosin merupakan 
protein hairpin-like dengan berat molekul 42 $\mathrm{kDa}$, yang menghubungkan membran plasma (nefrin) dan sitoskeleton podosit. Podosin berinteraksi dengan nefrin dengan ikatan lipid berbentuk rakit. Ikatan yang stabil dengan podosit menyebabkan podosin berperan penting dalam integritas struktural serta fungsional slit diaphragm terutama dalam fungsi mempertahankan permselectivity glomerulus. ${ }^{8}$

Telah dikenal 50 jenis mutasi gen NPHS2, yang meliputi mutasi nonsense, frameshift, dan missense, yang berbeda-beda pada tiap penyakit. ${ }^{8}$ Akhir-akhir ini telah diperkenalkan polimorfisme fungsional gen NPHS2, misalnya R229Q, pada ekson 5 nukleotida 755 terjadi pergantian basa $G$ oleh basa $A$ yang mengakibatkan substitusi Arg oleh Gls pada kodon 229. Hal ini dihubungkan dengan peningkatan risiko mikroalbuminuria pada populasi. Polimorfisme ini menjelaskan kemungkinan FSGS dihubungkan dengan mutan kedua alel NPHS2. ${ }^{8}$ Mutasi gen NPHS2 $412 \mathrm{C} \rightarrow \mathrm{T}$ dan 419 delG juga merupakan polimorfisme karena ditemukan selain pada anak SNRS juga ditemu-kan pada anak sehat $>1 \%$ pada anak-anak Indonesia. ${ }^{16} \mathrm{Hal}$ ini berbeda dengan penelitian di luar negeri terutama pada ras Eropa, dan Amerika, mutasi gen NPHS2 412C $\rightarrow$ T dan 419delG bukan suatu polimorfisme. Ini menunjukkan adanya perbedaan ras yang berpengaruh terhadap proses genetik.

\section{Transient Receptor Potential Cation 6 (TRPC6)}

Gen TRPC6 terletak pada kromosom 11 lengan pendek(11q24), menyandi protein TRPC6 yang merupakan bagian dari superfamili transient receptor potential (TRP), dan bersifat cationselective. Subfamili TRPC (TRPC1-TRPC7) bersifat selektif untuk ion kalsium yang penting untuk meningkatkan kadar kalsium intraselular setelah terikat dengan reseptor $\mathrm{G}$ dan reseptor tirosin kinase. TRPC6 penting untuk mengatur struktur dan fungsi podosit yang normal. Mutasi gen ini berhubungan dengan FSGS dominan otosom dan penyakitnya disebut FSGS2. ${ }^{8}$ Adanya dasar genetik pada penderita SN/FSGS familial membantu pemahaman mengenai mekanisme yang terjadi pada selektivitas ginjal dan terjadinya proteinuria. Adanya mutasi pada gen tertentu dapat menjelaskan usia terjadinya proteinuria, proteinuria yang timbul pada usia dini terjadi pada mutasi nefrin atau podosin, sedangkan proteinuria yang timbul pada usia lanjut terjadi pada mutasi gen ACTN4 atau TRPC6. ${ }^{8}$

\section{Alpha-actinin 4 (ACTN-4)}

Gen ACTN-4 terletak pada kromosom 19 lengan pendek (19q13), merupakan salah satu dari empat gen aktinin. Gen ini menyandi highly homologous proteins yang merupakan homodimer dengan ukuran $100 \mathrm{kD}$ dan satusatunya aktinin yang diekspresikan pada glomerulus manusia. ACTN-4 berperan penting dalam fungsi sitoskeletal nonmuscle yang terlibat dalam mempertahankan bentuk foot processes podosit. Mutasi ACTN-4 lebih jarang didapat dibanding mutasi gen NPHS1 atau NPHS2. Mutasi ini menyebabkan ikatan yang berlebihan antara ACTN-4 dan filamen aktin sehingga dapat merubah karakteristik mekanis podosit glomerulus. ${ }^{6}$ Penyakit akibat mutasi gen ACTN-4 disebut juga FSGS1, diturunkan secara otosom dominan, perbedaannya dengan yang diturunkan secara resesif, yaitu awitan yang lanjut dan progresivitas dari penyakit berjalan lambat. ${ }^{8}$ Identifikasi mutasi ACTN-4 pada pasien SN dengan FSGS otosom dominan menggambarkan besarnya peranan sitoskeleton pada fungsi glomerulus.

\section{Gen Wilms' Tumor (WT1)}

Gen Wilms' tumor (WT1) terletak pada kromosom 11p13, terdiri dari 10 ekson. Gen ini menyandi protein four zinc fingers. Ekspresi WT1 adalah salah satu faktor penting dalam perkembangan normal dari ginjal dan genitalia, mekanisme regulasinya hingga sekarang masih belum jelas. WT1 diekspresikan pada podosit pada tahap lengkung kapiler saat perkembangan podosit. Mutasi WT1 secara tipikal terlihat pada tumor Wilms sporadik dan kadang-kadang berhubungan dengan sindom Frasier dan sindrom Denys-Drash. Karakteristik kedua sindrom ini adalah disfungsi gonad dan nefropati progresif dengan FSGS atau sklerosis mesangial difus dengan awitan pada awal usia anak. ${ }^{6}$ Pada tahap diferensiasi lanjut, ekspresi WT1 mengalami penurunan kecuali pada sel epitel viseral (podosit) di glomerulus matur. Diperkirakan dengan pola ekspresi ini WT1 memiliki peran penting dalam induksi ginjal dan dalam tahap lanjut nefrogenesis. Beberapa bukti yang ditemukan menunjukkan bahwa WT1 ikut 
berperan dalam mempertahankan fungsi podosit normal, yaitu pertama WT1 mengalami mutasi pada 94\% dari keseluruhan penderita sindrom Denys-Drash serta hampir seluruhnya akan berkembang menjadi nefropati glomerulus, termasuk glomerulosklerosis.

\section{Laminin B2 Chain (LAMB2)}

LAMB2 adalah gen yang menyandi rantai laminin $\beta 2$, diekspresikan pada glomerulus dan membran basalis arteri, kapsul lensa, retina, lamina basalis otot polos intraokular, dan lamina basalis sinaps neuromuskular. Mutasi gen ini menyebabkan sindrom Pierson. Sindrom ini diturunkan secara otosom resesif dengan manifestasi SN kongenital dan abnormalitas mata yang khas. Histopatologi yang ditemukan adalah sklerosis mesangial difus. ${ }^{8}$

\section{Gen PLCE1 (NPHS3)}

Gen PLCE1 (NPHS3) adalah gen yang menyandi phospholipase PLCE1, terletak di lengan pendek kromosom 10 q23. Mutasi gen ini menyebabkan SNRS dengan gambaran histopatologi berupa diffuse mesangial sclerosis atau FSGS. Sindrom nefrotik ini adalah varian yang jarang ditemukan dari hereditary forms of childhood nephrotic syndrome, disebut juga nephrotic syndrome early onset type 3 karena mulai timbul pada usia dini dan akan berkembang secara progresif menjadi gagal ginjal terminal dalam waktu 5 tahun. ${ }^{14}$ Mutasi gen NPHS3 akan menyebabkan gangguan perkembangan podosit yang merupakan penyebab utama dari diffuse mesangial sclerosis.

Penyebab proteinuria pada SNRS adalah kerusakan fungsi atau struktur membran filtrasi glomerulus sebagai akibat kelainan dengan dasar imunologis ataupun karena kelainan gen. Peranan gen dalam mekanisme terjadinya SNRS berkaitan dengan perubahan susunan gen penyandi protein yang membentuk arsitektur celah diafragma. Mutasi gen ini menyebabkan kerusakan struktur celah diafragma, celah diafragma menjadi lebih lebar sehingga terjadi proteinuria yang berat. Perkembangan terakhir dari penelitian genetik molekuler telah menemukan delapan gen yang terlibat dalam patogenesis SN, yaitu: NPHS1, ACTN4, NPHS2, CD2AP, WT1, TRPC6, LAMB2, dan NPHS3. Protein yang disandi oleh gen-gen tersebut adalah: nefrin, $\alpha$-aktinin- 4 , podosin, CD2-associated protein, Wilms' tumor, transient receptor potential 6, laminin $\beta 2$ chain, dan phospholipase PLCE1. Sindrom nefrotik yang disebabkan mutasi gen akan memberikan manifestasi klinis yang lebih berat, onset lebih awal, tidak memberikan respons terhadap pengobatan steroid, dan akan cepat berkembang menjadi gagal ginjal terminal. Sindrom nefrotik karena mutasi gen tersebut di antaranya: FSGS otosom dominan yang disebabkan mutasi gen ACTN4, SN kongenital tipe Finnish (CNF) yang disebabkan mutasi gen NPHS1, dan FSGS baik familial ataupun nonfamilial yang disebabkan mutasi gen NPHS2.

Mutasi gen penyandi protein yang akan membentuk arsitektur celah diafragma dapat menyebabkan kerusakan struktur celah diafragma dengan akibat terjadinya SN berat dengan onset lebih dini dan resisten terhadap pengobatan kortikosteroid. Informasi tentang dasar genetik diharapkan dapat membantu memperkirakan perjalanan dan prognosis penyakit.

\section{Daftar Pustaka}

1. Niaudet P. Podocin and nephritic syndrome: implications for the clinician. J Am Soc Nephrol. 2004;15:823-34.

2. Bagga A, Mantan M. Nephrotic syndrome in children. Indian J Med Res. 2005;122:13-28.

3. Ruf RG, Lichtenberger A, Karle SM, Haas JP, Anacleto FE, Schultheiss M, dkk. The APN study group. Patients with mutations in NPHS2 (Podocin) do not respond to standard steroid treat-ment of nephrotic syndrome. J Am Soc Nephrol. 2004;15:722-32.

4. Antignac C. Genetic models: clues for understanding the pathogenesis of idiopathic nephrotic syndrome. J Clin Invest. 2002;109:447-9.

5. Huber TB, Simons M, Hartleben B, Sernetz L, Schmidts M, Gundlach E. Molecular basis of the functional podocin-nephrin complex: mutations in the NPHS2 gene disrupt nephrin targeting to lipid raft microdomains. Hum Mol Genet. 2003; 12:3397-405.

6. Vats AN. Genetics of idiopathic nephrotic syndrome. Indian J Pediatr. 2005;72:777-84.

7. Niaudet P. Genetic forms of nephrotic syndrome. Pediatr Nephrol. 2004;19:1313-8.

8. Obeidova H, Merta M, Reiterova J, Maixnerova 
D, Stekrova J, Rysava R, dkk. Genetic basis of nephrotic syndrome-review. Prague Med Report. 2006;107(1):5-16.

9. Reidy K, Kaskel FJ. Pathophysiology of focal segmental glomerulosclerosis. Pediatr Nephrol. 2007;22:350-4.

10. Kwoh C, Shannon MB, Miner JH, Shaw A. Pathogenesis of nonimmune glomerulopathies. Annu Rev Pathol Mech Dis. 2006;1:349-74.

11. Asanuma K, Mundel P. The role of podocytes in glomerular pathobiology. Clin Exp Nephrol. 2003;7(4):255-9.

12. Antignac C. Genetic models: clues for understanding the pathogenesis of idiopathic nephrotic syndrome. J Clin Invest. 2002; 109:447-9.

13. Caridi G, Bertelli R, Duca MD, Dagnino M,
Emma F, Muda AO, dkk. Broadening the spectrum of disease related to podocin mutations. J Am Soc Nephrol. 2003;14:1278-86.

14. Hinkes BG. NPHS3: new clues for understanding idiopathic nephrotic syndrome. Pediatr Nephrol. 2008;18:847-50.

15. Kuusniemi AM. Pathophysiology of congenital nephrotic syndrome of the Finnish type [disertasi]. Helsinki: University of Helsinki; 2007.

16. Rachmadi D. Mutasi gen NPHS2, atopi, dan jenis kelamin sebagai faktor risiko sindrom nefrotik resisten-steroid dan perbedaan manifestasi klinis-nya berdasarkan mutasi gen NPHS2 (disertasi). Bandung: Universitas Padjadjaran; 2009. 